\title{
A Tribute to Nicholas Stephen Novakowski 1925-2004
}

\author{
JOSEPH E. BRYANT \\ 447 Thessaly Circle, Ottawa, Ontario K1H 5W7 Canada \\ Bryant, Joseph E. 2006. A tribute to Nicholas Stephen Novakowski 1925-2004. Canadian Field-Naturalist: 120(3): \\ 370-378.
}

Nicholas Stephen Novakowski was an enthusiastic and very knowledgeable wildlife and fisheries scientist. Although his list of published works is modest, he was well known and respected across Canada and in several international fora. He has been credited as "the person who saved the Wood Bison as a discrete subspecies" (W. E. Stevens, personal communication) and was highly engaged in the early years of the surveys and recovery of the Whooping Crane (Novakowski, 1965b, 1966). Following those early days at Fort Smith, North West Territories, Nick was transferred first to the Edmonton office of the Canadian Wildlife Service and then to CWS headquarters in Ottawa where he was appointed Staff Specialist, Mammalogy, and took on national and international responsibilities. He retired in 1983 but continued his strong support for endangered wildlife and their habitats until his death on 3 July 2004 in Ottawa. He is survived by his wife, Amy, and two sons, Kent, a professor of hydrogeology and environmental engineering at Queen's University and Erin Nicholas, a professor of geography and environmental studies at Memorial University.

Nick was born 28 November 1925 in Mundare, Alberta (about $70 \mathrm{~km}$ east of Edmonton), the second child and eldest son in a family of 10 children. His father owned a Chrysler dealership and garage and from an early age Nick learned about all things mechanical a fact that would stand him in good stead in later years as a field biologist. He also developed an abiding loyalty to Chrysler products and, briefly, owned only one automobile that didn't bear that company's mark. Finding the alternate car highly unreliable, he soon returned to his original choice and did not waver again. In his younger years he was a superb athlete. He and his brothers Archie and Van were well known in central Alberta hockey circles as a high-scoring powerhouse. Nick, who was ambidextrous, could play either wing and was a sharp goal tender (Ken Novakowski, personal communication). Also in those early years he became an ardent angler and as often as possible visited members of his extended family who lived in towns north of Edmonton. One of his favourite spots was Siebert Lake. Just a couple of weeks before his death he very happily returned there with his sister, Sharon, and her husband to renew those earlier experiences - with considerable success. Time had not dulled his expertise.

Nick entered the University of Alberta in 1947 and in the following two summers worked on forest fire suppression crews based in Fort Smith, North West Territories. There he became acquainted with Bill Fuller, the resident mammalogist for the Canadian Wildlife Service. He graduated with a B.Sc. in Chemistry in 1950 and that summer returned north but this time he was hired by Northern Transportation Company Limited (NTCL) for summer work on the docks at the company's shipping base near Fort Smith. At that time NTCL gave hiring priority to young men who could enhance its baseball team and Nick "was a very good ball player" (W. A. Fuller, personal communication). Nick returned to the University of Alberta that autumn to begin a Master's program and went back to Fort Smith in the spring of 1951 . That autumn Dr. Fuller was assigned to conduct research of Wolves in Wood Buffalo National Park (WBNP) and adjacent areas of the Mackenzie District and employed Nick as an assistant (see Fuller and Novakowski 1955). Nick also helped Fuller with his studies of Beaver and with the "autopsies of lone, crippled, bison we encountered from time to time" (W. A. Fuller, personal communication). It was the start of Nick's wildlife and fisheries career, and perhaps of equal importance, the start of the romance that led in June 1952 to his marriage to the love of his life, Amy Swartz, a Fort Smith school teacher from Saskatchewan.

Also in 1952, with Fuller's recommendation, Dr. D. S. Rawson accepted Nick for graduate studies in fisheries at the University of Saskatchewan. Over the next few years he worked very happily at his studies and as a fisheries biologist for the Government of Saskatchewan. Although only one published paper appears to have resulted from that work (Atton and Novakowski 1956), he authored or co-authored many in-house reports for the Saskatchewan government dealing with fisheries research and resource management. Amy Novakowski tells me that those were the happiest years of Nick's life - helped, no doubt, by the fact that Amy was able to accompany him on many of his extended field studies in northern Saskatchewan. The photograph accompanying this article was taken at that time.

After completing his M.Sc., (Novakowski 1955c*) Nick was hired by the Canadian Wildlife Service in 1956 and sent to Fort Smith. His mentor, Dr. Fuller, was transferred that year to Whitehorse, Yukon, and Nick dived immediately into Dr. Fuller's continuing studies of Beaver populations in the southwestern Northwest Territories, Wolves in Keewatin District (Flook and 


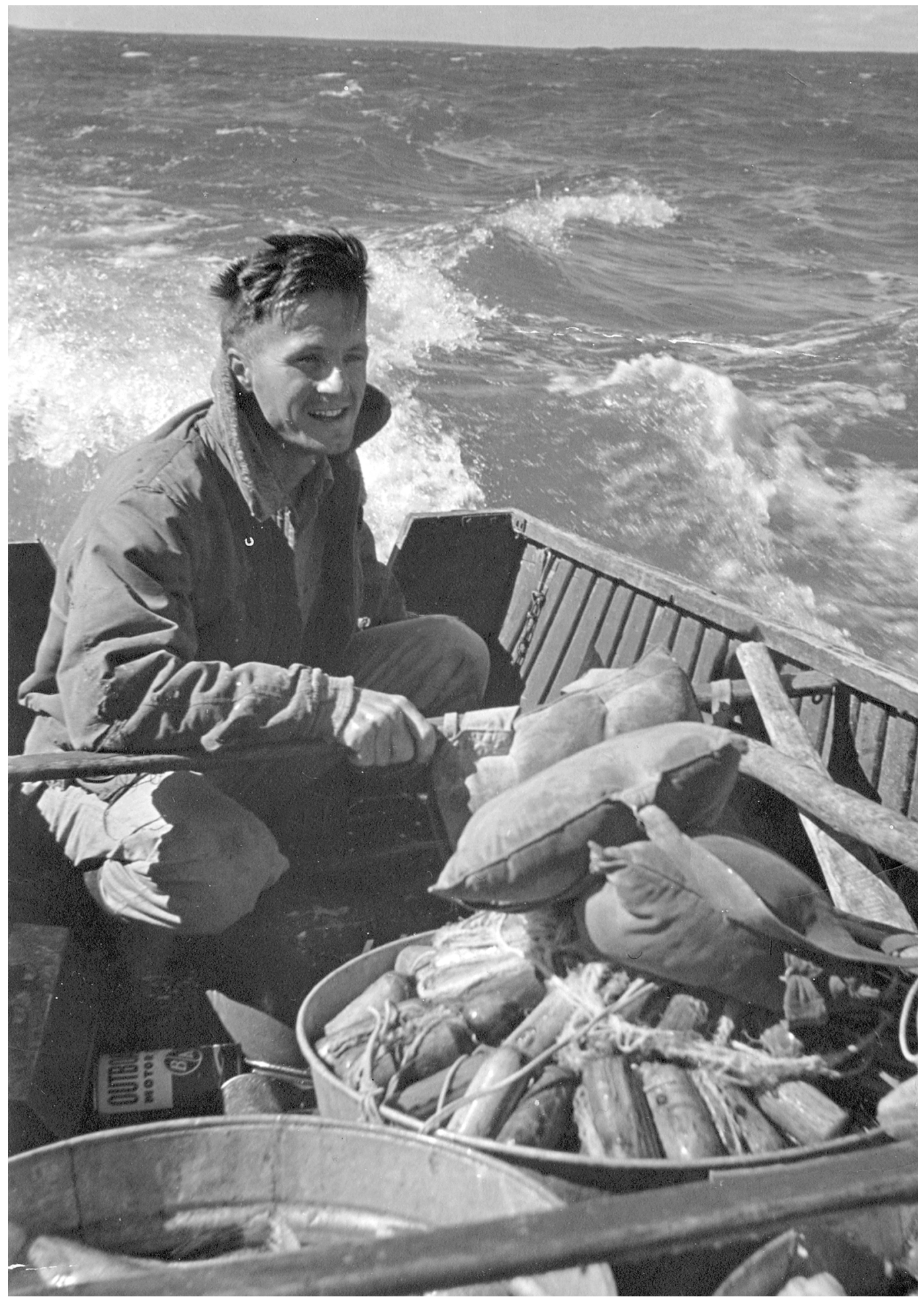

FIGURE 1. Nick Novakowski, fisheries researcher, Lac des Iles, Saskatchewan, 1955. 
Novakowski 1956*; see also Novakowski 2003) and Bison and Whooping Cranes in Wood Buffalo National Park.

In 1957, in the course of an aerial survey of Bison in WBNP, he discovered the presence of an isolated herd of Bison in the Nyarling River area in the northwest corner of the Park (Banfield and Novakowski 1960). Subsequent aerial and ground studies indicated that the herd might be Wood Bison genetically uncontaminated by the Prairie Bison that had been transferred to WBNP in the 1920s. In 1959, Nick was able to obtain specimens which were confirmed by the National Museum to be Wood Bison (Banfield and Novakowski 1960). In the following three years he arranged for over 70 live specimens to be trapped and tested for tuberculosis and brucellosis. Of those, 18 that were disease-free were moved in February 1963 to a large holding corral northwest of Fort Smith. Three calves arrived that spring and in early summer all of the animals were again tested for disease. All were clear. Nick had previously scouted out appropriate habitat north of Fort Providence, North West Territories (Novakowski, 1959d*), and 18 disease-free Wood Bison, including the new calves, were transported there in August 1963. That area, now known as the Mackenzie Bison Sanctuary, proved to be an excellent site and the small nucleus soon swelled. Subsequently other specimens were taken from the Nyarling River site, transferred to Elk Island National Park, and after a rigorous clean-up protocol, produced another disease-free herd of Wood Bison (Gates et al. 2001). Some of Nick's less well-known Bison research included "the first use of dental annuli to estimate the age of bison" (Christianson et al. 2005). The same authors also credit him with being the first to measure and to demonstrate the usefulness of other Bison dentition measurements in aging large samples.

In 1958, Nick was also in charge of stocking Pine Lake and a few smaller lakes in WBNP with Rainbow Trout. He established and operated a small hatchery for that purpose, putting his Saskatchewan fisheries experience to good purpose (Novakowski 1958c*, 1959c*).

In 1962, when anthrax struck the Bison population just outside WBNP, it was the first recognized instance in Canada of anthrax in wildlife and all concerned were faced with a very steep learning curve. Nick worked closely with a team of scientists from the Canadian Wildlife Service, the Health of Animals Branch of the federal Department of Agriculture, and medical personnel to bring it under control (Novakowski et al. 1963; Choquette et al. 1972).

Dr. Fuller had engaged the interest of a long-time trapper in the southern portion of WBNP, Solomon Lacaille, to help with Muskrat studies (Fuller 1951). Nick followed through and set up a multi-year study on Mr. Lacaille's trapline to study many aspects of beaver biology and ecology, leading to his Ph.D. from the University of Saskatchewan in 1965 (Novakowski 1965a*, 1967a, 1969a).
The nesting grounds of the Whooping Crane, long an international mystery, were discovered in 1954 in the northern portion of Wood Buffalo National Park. In the subsequent two years the site was monitored by Dr. W. A. Fuller. Nick took over those studies in 1956 and monitored the small breeding population for several years (Novakowski 1966, 1967d). He was also responsible for capturing an injured juvenile whooper in 1964 and for ensuring its safe conduct to the breeding facility of the United States Fish and Wildlife Service near Washington, D.C. (Novakowski 1965b, 1965e*). That bird, a male named "Canus" for its dual nationality, sired "over 180" (E. Kuyt, personal communication) Whooping Cranes over its long career. It died in January 2003. The mounted body was repatriated to Canada and is now installed at the Northern Life Museum in Fort Smith, N.W.T. (E. Kuyt, personal communication).

Nick's work on Wood Bison and Whooping Cranes introduced him to the burgeoning field of rare and endangered species. It was a field that would occupy much of his attention for the remainder of his life. The Canadian Wildlife Service moved Nick to a Staff role in Ottawa in 1966. J. Anthony Keith, who was Nick's immediate superior in the Canadian Wildlife Service for much of his time in Ottawa, reported that "Nick Novakowski was the founding voice in CWS headquarters for wide-scale collaborative action on endangered species, beginning in 1967 when he was Staff Specialist, Mammalogy. While his own earlier work on Whooping Cranes became the trademark federal endangered species project, there was a continuing debate amongst headquarter staff about how far CWS should get involved in endangered species work. Nick had to argue against those who saw it as a diversion of limited resources from urgent wildlife conservation issues. He worked with Ted Mosquin to produce the first set of scientific articles in Canada on endangered vertebrates (The Canadian Field-Naturalist 84(1) 1970), writing the article on mammals." [See Novakowski 1970b].

In 1973, Nick represented the Canadian Wildlife Service at the international negotiations in Washington of what became the Convention on International Trade in Endangered Species of Wild Fauna and Flora (CITES). While John Heppes joined CWS to establish the Canadian management authority for CITES, Nick chaired the scientific authority until he retired in 1983 (Burnett 1999, page 162).

Nick Novakowski and John Heppes worked well together. Their first task was to convince provincial governments that CITES would not interfere with provincial authority over wildlife resources. John dealt with the administrators and enforcement personnel while Nick met with the wildlife managers and scientists. "Nick showed an amazing understanding and ability in persuading all concerned to fully cooperate ..." (J. Heppes, personal communication). Canada ratified the Convention in early 1975 . Every two years there was 
a "Conference of the Parties" at which member nations negotiated changes. "It was at these Conferences that Nick really proved his worth. In his role as Scientific Advisor he was always able to present the Canadian viewpoint in a clear and concise manner. While usually a calm and collected person, Nick could at times be very forceful in getting the Canadian opinion across ... he was respected by many international authorities who often sought his advice on biological status of endangered species and his assistance in presenting their positions." (J. Heppes, personal communication).

Eugene Lapointe, the first Secretary General of CITES, remembers Nick's contributions for their scientific rigour and said, "My recollection of Nick is that he played a key role at the CITES meeting held in Gabarone, Botswana in 1983. The international community had an opportunity to realize what real and credible science was all about, and that thanks to Nick. I always perceived him as one of the most candid scientists. He was highly respected by his peers from the CITES community" (E. Lapointe, personal communication).

I recall one meeting in Ottawa where Canadian NonGovernment Organizations (NG0s) were presenting their concerns about an upcoming Conference of the Parties. Two delegates were particularly vociferous in their assault on a proposed Canadian position. Nick as usual was thoroughly prepared and met both scientific and emotional arguments with calm, well-reasoned, non-confrontational responses which won the day.

Nick was also front and centre in the discussions leading up to the establishment of the Committee on the Status of Endangered Wildlife in Canada (COSEWIC). Ted Mosquin recalled that as he was preparing draft recommendations for an upcoming symposium on Canada's Threatened Species and Habitats in 1975 Nick suggested that he look into the UK model that had "a unique committee that addressed the matter of the status of endangered species in the UK. [Nick] came over to the CNF office to fill me in on how the UK system worked. The result was a draft recommendation ... which led to almost immediate establishment of COSEWIC by agreement of CWS and provincial agencies via the Federal Provincial Wildlife Conference" (T. Mosquin, personal communication).

"Throughout Nick's work as a senior scientist in headquarters, he maintained a network of colleagues in provincial and territorial governments. Nick's credibility with these colleagues was vital in their governments' agreement in 1977 to the initiative that became the Committee on the Status of Endangered Wildlife in Canada (COSEWIC), with Nick elected as its first permanent secretary. During the first formative years of COSEWIC Nick did outstanding work helping to forge a new way of doing business, helping to bring federal, provincial, territorial and non-government agency people to agree on publicly-released status reports. Making public the facts about endangered species was what Nick had been calling for since 1967 , believing that this would lead to remedial actions supported by the public. COSEWIC continued to grow in the spirit of Nick's early aspirations, and recently was established as a formal entity under the Species at Risk Act." (J. A. Keith, personal communication).

In addition to Nick's work as COSEWIC secretary, he maintained his avid interest in species biology. He wrote the original Wood Bison status report and contributed to others. He also chaired the Marine Mammal and Terrestrial Mammal subcommittee in 1980 and, when it split, he chaired the Terrestrial Mammal subcommittee from 1981 to 1984.

Dr. Novakowski was involved in a much broader scope of activities than this review can encompass but three items may help to round out the story. For a number of years in the 1960s and 1970s he was involved with the search for more humane traps for capturing furbearers. His field experience with trappers proved very useful. He thoroughly understood the trappers' needs (Novakowski 1958d*) and also the political pressure being created to do away with the leg-hold trap. In 1967 he gave a brief but cogent review of the problem to the Federal-Provincial Wildlife Conference (Novakowski 1967e) and continued to be involved with the resulting program to develop humane traps until his retirement. Another example of his varied work involved blocking the introduction by an Ontario fur rancher of several dozen Raccoon Dogs (Nyctereutes procyanoides) from Finland. When the news arrived on Nick's desk, he nearly blew a fuse! He was one of the very few people in Canada who had the knowledge to foresee a disastrous outcome if those animals were allowed to stay. He knew from the literature and from his many European colleagues that if the animals ever got loose the species could have devastating ecological effects. And he knew that no matter what precautions were taken, sooner or later some of them would get loose. He sought the assistance of Dr. Eric Broughton, a veterinarian with the CWS, to have Agriculture Canada deny the import permit. No dice - there was no basis for denial on environmental grounds. Nevertheless, based on knowledge of the ecology of the species, he convinced Canadian authorities that the animals posed an unacceptable threat to Canadian wildlife and obtained authorization to have all of the imports killed, the pelts processed by the Hudson's Bay Company and compensation made to the owner. But he didn't leave it there. Nick pursued the problem domestically and with the United States authorities resulting in a formal Canada-USA agreement to bar the future importation or Raccoon Dogs into either Canada or the USA (E. Broughton, personal communication). A third dimension of Nick's professional work involved teaching a variety of courses, including biology, terrestrial ecology, and wildlife management at University of Ottawa, the University of Guelph, and Sir Sandford Fleming College in Lindsay, Ontario.

After retiring from the Canadian Wildlife Service in 1983, Dr. Novakowski became active as a scientific 
consultant and engaged in a wide range of projects. In some cases he worked independently. In most he served as a member of a consulting team. In one of his early projects, he worked with Ted Mosquin to consolidate and review many earlier reports on Caribou and fur-bearers in Pukaskwa National Park (Novakowski and Mosquin 1986a*, b*, $\left.\mathrm{c}^{*}, \mathrm{~d}^{*}\right)$. Dr. Mosquin recently commented: "Nick provided the publications/ reports, guidelines, policies, appendices, survey data, illustrations, etc. as well as some text. I basically organized and wrote the reports based on the material and discussions. He was the expert. We worked well together and I learned a lot! ... We sometimes sat for more than a few hours trying to figure out what needed to be said and how to best say it."

Several of Dr. Novakowski's post-retirement projects dealt with major Environmental Impact Assessments of such projects as the Military Low-Level Flying program in Labrador, uranium mining in northern Saskatchewan, the Rafferty-Alameda dams proposal in southern Saskatchewan, military base proposals in the arctic, and bison management in Wood Buffalo National Park. He became very knowledgeable about environmental impact assessments in Canada and contributed behind the scenes on a variety of policy issues. He also contributed to a review paper on the evolution of environmental impact assessments of watershed modification projects (Dirschl et al. 1992).

In 1982, a year before Nick retired from the Canadian Wildlife Service, Dr. Husain Sadar arrived at the Federal Environmental Assessment Review Office (FEARO). In a letter following Nick's death, Dr. Sadar wrote that one of his "major responsibilities was to organize teams of highly recognized, accomplished and credible independent experts and specialists to assist and advise [the independent review panels] for analyzing and addressing often complex scientific, technical and socio-economic issues ... Nick served as an independent expert for several panels [dealing with] some of the most difficult, controversial and complex mega project proposals ... the panels benefited immensely from Nick's unique experiences and expertise in wildlife management and habitat protection. Whether the issue was protection of caribou herds, moose, large carnivores, furbearers, waterfowl, seabirds, birds of prey, marine birds or deer, Nick's critical analysis, evaluation and resolution of all such issues was simply outstanding ... But the most important quality of Nick's wonderful character was his ability to interact and work with other professionals in a highly professional, civilized and friendly fashion. He truly was a real gentleman."

Dr. Herman Dirschl, with whom Dr. Novakowski collaborated on many contracts, recalled their joint efforts on some of those major projects and commented, inter alia that, "Nick could be very passionate in his views, particularly when political decisions seemed to often favour short term economic gains at the expense of the long term environmental health. However, he managed to always stay calm and collected in the face of such adversity. I admired him for this ability and will greatly miss him.' Dr. Dirschl also recalled their work "on an assessment of priority habitat sites throughout Canada to be considered for protection by the Canadian Wildlife Service in concordance with the Federal Government's 'Green Plan' goals. Nick took on the responsibility for reviewing the site records for a total of 262 sites in all provinces and territories; designing a classification system and defining latitude/longitude centroids for each site."

Even Canada Post sought out Dr. Novakowski's advice in planning for a commemorative postage stamp featuring Beaver - the $150^{\text {th }}$ anniversary of the original $3 \not$ Beaver stamp (Novakowski 1997*).

Nick the scientist was also Nick the practical environmentalist. Early in their stay in Ottawa he and his wife, Amy, bought 150 acres of forested land in nearby Lanark County. It was covered primarily with second growth hardwoods but also had a small plantation of Red Pine which Nick carefully nurtured. He became very interested in the "Model Forest" concept and was a very keen member of the "Eastern Ontario Certified Forest Owners."

I leave the closing words to his good friend, car pool partner and long-time professional colleague, Gerry Lee: "On a house visit one day, Nick invited me into his garage to see his latest pride and joy. There sat a beautiful cedar strip canoe, like a collector's piece of rare furniture, hand built by canoe builder Nick for one of his offspring. Apart from the odd comment previously about 'building a boat someday,' I had no inkling of his interest or talent in this area. So much for thinking you know someone! To sum up, Nick to me was the consummate good guy; respected professional, devoted family man, equally devoted environmentalist, polite, humble and honest. A good friend I'll never forget."

\section{Acknowledgments}

Nick's wife, Amy, was very supportive, provided copies of important papers, and authorized the use of the photograph used in this tribute. His brother, Ken, provided details of Nick's early family life. Several librarians were especially helpful in assembling the lists of Dr. Novakowski's publications and unpublished reports: Terri Fraser, Canadian Wildlife Service, Edmonton; Jean-François Bélanger, Environment Canada Library, Gatineau, Quebec; Carol Schurr, former librarian, and Rob Wallace, Fisheries Ecologist, Saskatchewan Resource Stewardship Branch, Saskatoon; Staff, Library and Archives Canada, Ottawa, and Keith Van Cleave, Librarian, Northern Prairie Wildlife Research Centre, Jamestown, North Dakota. Many former colleagues of Dr. Novakowski provided assistance: I thank in particular Bill Fuller, Tony Keith and Gerry Lee for their contributions and for their very helpful comments on an earlier draft of this paper. Additional thanks are due 
Eric Broughton, Herman Dirschl, Don Flook, Andy Hamilton, John Heppes, Ernie Kuyt, Eugene Lapointe, Alan Loughrey, Ted Mosquin, Doug Pollock, Dick Russell, Husain Sadar, Ward Stevens, John Tener and Don Thomas. I also thank my wife, Mary Bryant, for her constant support and assistance.

Literature Cited (exclusive of items listed in Bibliography) Burnett, J. A. 1999. A passion for wildlife: A history of the Canadian Wildlife Service, 1947-1997. The Canadian Field-Naturalist 113(1) 1-214.

Christianson, D. A., P. J. P. Gogan, K. M. Podruzny, and E. M. Olexa. 2005. Incisor wear and age in Yellowstone bison. Wildlife Society Bulletin 33(2): 669-676.

Fuller, W.A. 1951. Natural history and economic importance of the muskrat in the Athabasca-Peace delta, Wood Buffalo Park. Canadian Wildlife Service, Wildlife Management Bulletin Series 1, Number 2, 82 pages, charts, photographs.

Gates, C. C., R. O. Stephenson, H. W. Reynolds, C. G. vanZyll de Jong, H. Schwantje, M. Hoefs, J. Nishi, N. Cool, J. Chisholm A. James, and B. Koonz. 2001. National Recovery Plan for the Wood Bison (Bison bison athabascae). National Recovery Plan Number 21. Recovery of Nationally Endangered Wildlife (RENEW). Ottawa, Ontario. 50 pages.

Munro, D. A. 1973. Introductory remarks. Pages 28-29 in Convention on International Trade in Endangered Species of Wild Fauna and Flora. Transactions, $37^{\text {th }}$ Federal-Provincial Wildlife Conference, Ottawa.

\section{Bibliography}

This bibliography is divided into published and unpublished sections. While many of Nick's reports were never published, their listing helps to demonstrate the breadth of his professional activities. Most reports prepared for the Federal Environmental Assessment and Review Office (FEARO) are not listed, in line with the terms of the contracts under which they were produced. Listings are chronological irrespective of whether Nick was the sole author, lead author or junior author.

\section{Publications}

Fuller, W. A., and N. S. Novakowski. 1955. Wolf control operations, Wood Buffalo National Park, 1951-52, Canadian Wildlife Service. Wildlife Management Bulletin, Series 1, Number 11. [2] + 20 pages, photographs.

Novakowski, N. S. 1956. Additional records of bats in Saskatchewan. Canadian Field-Naturalist 70: 142.

Atton, F. M., and N. S. Novakowski. 1956. The value of freshwater fish as a mink food. Fur Trade Journal of Canada 33 (11): 12-13, 38, 40-42.

Banfield, A. W. F. and N. S. Novakowski. 1960. The survival of wood bison (Bison bison athabascae Rhodes) in the Northwest Territories. Natural History Paper Number 8, National Museum of Canada. 6 pages, illustrations, map, tables.

Novakowski, N. S., J. H. G. Cousineau, G. B. Kolenosky, G. S. Wilton, and L. P. E. Choquette. 1963. Parasites and diseases of bison in Canada. II. Anthrax epizootic in the Northwest Territories. Pages 233-239 in the Transactions of the $28^{\text {th }}$ North American Wildlife and Natural Resources Conference. Wildlife Management Institute, Washington, D.C. [CWSC 1357].
Novakowski, N. S. 1965a. Cemental deposition as an age criterion in bison, and the relationship of incisor wear, eye-lens weight, and dressed bison carcass weight to age. Canadian Journal of Zoology 43: 173-178. [CWSC 1426].

Novakowski, N. S. 1965b. The day we rescued a whooping crane. Audubon Magazine 67: 230-233.

Novakowski, N.S. 1966. Whooping crane population dynamics on the nesting grounds, Wood Buffalo National Park, Northwest Territories, Canada. Canadian Wildlife Service, Report Series Number 1. 19 pages, illustrations, tables, maps.

Novakowski, N. S. 1967a. The winter bioenergetics of a beaver population in northern latitudes. Canadian Journal of Zoology 45 (6): 1107-1118.

Novakowski, N. S. 1967b. Conservation of rare and endangered species of mammals in Canada. Pages 73-75 in the Transactions of the $31^{\text {st }}$ Federal-Provincial Wildlife Conference, Ottawa.

Novakowski, N.S. 1967c. Humane trapping. Transactions of the $31^{\text {st }}$ Federal-Provincial Wildlife Conference, Ottawa. Pages 67-68.

Novakowski, N. S. 1967d. Whooping crane. Modern Game Breeding 3 (6): 19-25, 35-41, 43. [A reprint of most of Novakowski 1966]

Novakowski, N. S. 1967e. Beaver - Wood Buffalo National Park. Page 48 in Canadian Wildlife Service '66. Queen's Printer, Ottawa. Catalogue Number RR66-3766.

Novakowski, N. S. 1967f. Bison - Wood Buffalo National Park. Page 48 in Canadian Wildlife Service '66. Queen's Printer, Ottawa. Catalogue Number RR66-3766.

Novakowski, N. S. 1968a. The National Committee on Wildlife Land Meeting, May 28-30, 1968. Pages 22-23 in the Transactions of the $32^{\text {nd }}$ Federal-Provincial Wildlife Conference, Ottawa.

Novakowski, N. S. 1968b. The Export-Import Convention. Page 27 in the Transactions of the $32^{\text {nd }}$ Federal-Provincial Wildlife Conference, Ottawa.

Novakowski, N. S. 1968c. Humane Trapping. Pages 27-29 in the Transactions of the $32^{\text {nd }}$ Federal-Provincial Wildlife Conference, Ottawa.

Novakowski, N. S. 1969a. The influence of vocalization on the behavior of beaver, Castor canadensis Kuhl. American Midland Naturalist 81: 198-204.

Novakowski, N.S. 1969b. Report on the Administrative Committee for Polar Bear Research and Management in Canada. Page 22 in the Transactions of the $33^{\text {rd }}$ Federal-Provincial Wildlife Conference, Ottawa.

Novakowski, N. S. 1970a Endangered wildlife - mammals. Pages 6-7 in Endangered Wildlife in Canada. Canadian Wildlife Federation, Ottawa, Ontario.

Novakowski, N. S. 1970b. Endangered Canadian mammals. Canadian Field-Naturalist 84(1): 17-23.

Jeffrey, W. W., C. S. Brown, M. Jurdant, N. S. Novakowski, and R. H. Spilsbury. 1970. Foresters and the challenge of integrated resource management. The Forestry Chronicle, June: 196-199.

Choquette, L. P. E., E. Broughton, A. A. Currier, J. G. Cousineau, and N. S. Novakowski. 1972. Parasites and diseases of bison in Canada. III. Anthrax out-breaks in the last decade in northern Canada and control measures. Canadian Field-Naturalist 86: 127-132.

Novakowski, N. S. 1973a. Natural resources in the Northwest Territories and the Yukon. Pages 91-97 in Natural Resource Development in Canada. Edited by Phillippe Crabbe and Irene Spry. University of Ottawa Press. 
Novakowski, N.S. 1973b. Report of the Administrative Committee for Caribou Preservation. Page 75 in the Transactions of the $37^{\text {th }}$ Federal-Provincial Wildlife Conference, Ottawa.

Novakowski, N. S., and V. E. F. Solman. 1975. Potential of wildlife as a protein source of food. Journal of Animal Science 40(5): 1016-1019.

Novakowski, N.S. 1976. Endangered species. Pages 28-31 in the Transactions of the $39^{\text {th }}$ Federal-Provincial Wildlife Conference, Ottawa.

Novakowski, N. S. 1977. [an edited version of Dr. Novakowski's statements as a witness on behalf of the Canadian Wildlife Federation before the National Energy Board hearings into a Mackenzie Valley Pipeline.] Pages 24A-24E in Wildlife Report. The Canadian Scene. May-June 1977. Canadian Wildlife Federation.

Choquette L. P. E., E. Broughton, J. G. Cousineau, and N. S. Novakowski. 1978. Parasites and diseases of bison in Canada. IV. Serologic survey for brucellosis in bison in northern Canada. Journal of Wildlife Diseases 14(3): 329-332.

Novakowski, N. S., and Geoff Robins. Editors. 1982. Proceedings, Symposium on Natural Resources Use and Native Rights in Canada. Canadian Society of Environmental Biologists, Ottawa. 105 pages. [EC-E] [EC-O]

Novakowski, N. S. 1984. Control of mammals at airports. Pages 183-186 in Proceedings, Wildlife Hazards to Aircraft. Conference and Training Workshop, Edited by M. J. Harrison, S. A. Gauthreaux and L. A. Abron-Robinson. U.S. Department of Transportation; Federal Aviation Administration; Office of Airport Standards, Charleston, North Carolina.

Hill, E. P., and N. S. Novakowski. 1984. Beaver management and economics in North America. Acta Zoologica Fennica 172: 259-262.

Novakowski, N. S. 1985. Beaver management in Canada; a review. Proceedings of the $4^{\text {th }}$ International Theriological Congress, Edmonton, Alberta. [Abstract] Session S08.

Dirschl, H. J., N. S. Novakowski, and M. H. Sadar. 1993. Evolution of environmental impact assessment as applied to watershed modification projects in Canada. Environmental Management 17(4): 545-556.

Novakowski, N. S. 2003. The Wilson River Escapade. Pages 8-10 in Then: Friends sharing memories. Edited and published by Mary and Joe Bryant, Ottawa. vii + 256 pages, illustrations. ISBN 0-9733372-0-6.

Unpublished papers (marked $*$ where cited) $[\mathrm{EC}-\mathrm{E}]=$ Canadian Wildlife Service Library, Edmonton. [EC-O] = Environment Canada Library, Ottawa (Gatineau, Quebec). [ES-S $]=$ Environment Saskatchewan, Saskatoon.

Atton, F. M., and N. S. Novakowski. 1953a. Utilisation of fish on mink ranches in the Buffalo Narrows Region. Fisheries Technical Report 53-1. 17 pages. [ES-S]

Atton, F. M., and N. S. Novakowski. 1953b. The value of freshwater fish as mink food. Fisheries Technical Report 53-5. 10 pages. [ES-S] (See also published version, Atton and Novakowski, 1956.)

Atton, F. M., and N. S. Novakowski. 1954a. Analysis of sampling the commercial fishery of Lake Athabasca, 1951-1953. Fisheries Technical Report 54-4. 11 pages. [ES-S]

Atton, F. M., and N. S. Novakowski. 1954b. Analysis of sampling the commercial fishery of Lake Athabasca, 1954. Fisheries Technical Report 55-3. 7 pages. [ES-S] [EC-E]
Novakowski, N. S. 1955a. Report on biological and fisheries survey of Reindeer Lake, 1954. Fisheries Technical Report 55-1. 62 pages. [ES-S]

Novakowski, N.S. 1955b. The ecology of Reindeer Lake with special reference to fish. Fisheries Manuscript Report M-4. 62 pages. [ES-S]

Novakowski, N.S. 1955c. The ecology of Reindeer Lake with special reference to fish: a thesis submitted to the Faculty of Graduate Studies in partial fulfillment of the requirements for the degree of Master of Science in the Department of Biology, University of Saskatchewan. 99 pages, 2 fold-out maps, figures.

Atton, F. M., and N. S. Novakowski. 1956a. Biological survey and fisheries management of Waterhen Lake and adjoining lakes. Fisheries Technical Report 56-4. 50 pages. [ES-S]

Atton, F. M., and N. S. Novakowski. 1956b. Biological survey and fisheries management of Lac des Iles. Fisheries Technical Report 56-3. 34 pages. [ES-S]

Atton, F. M., and N. S. Novakowski. 1956c. Biological survey and fisheries management of Jackfish and Murray Lakes. Fisheries Technical Report 56-2. 66 pages. [ES-S]

Atton, F. M., and N. S. Novakowski. 1956d. The value of freshwater fish as mink food. Fisheries Technical Report. 2 pages. [ES-S] (See also published version, Atton and Novakowski 1956.)

Novakowski, N. S. 1956a. Analysis of autopsy records of wolves taken in the Eskimo Point area 1956. Canadian Wildlife Service, CWSC 51: 12 pages, 2 tables. [EC-E] [EC-0]

Novakowski, N.S. 1956b. Resurvey of beaver habitat in the Fort Simpson, Fort Liard and Wrigley areas, 1956. Canadian Wildlife Service, CWSC 753: 4 pages, maps, illustrations. [EC-E] [EC-0]

Flook, D. R., and N. S. Novakowski. 1956. An experiment in poisoning wolves on the arctic tundra. Part A. CWSC 49: 9 pages, 2 maps. [EC-O]

Novakowski, N. S. 1957a. Aerial resurvey of bison in Wood Buffalo National Park and surrounding areas, 1957. Canadian Wildlife Service, CWSC 216: 12 pages, maps. [EC-E] [EC-O]

Novakowski, N. S. 1957b. Report on tagging, testing and slaughtering of bison in the Lake Claire area Wood Buffalo National Park, October, November 1957. Canadian Wildlife Service, CWSC 728: 14 pages. [EC-E] [EC-O]

Novakowski, N.S. 1958a. Report on the testing, tagging and slaughter of bison in Wood Buffalo National Park, OctoberNovember, 1958. Canadian Wildlife Service, CWSC 764: 18 pages, illustrations, charts. [EC-E] [EC-O]

Novakowski, N.S. 1958b. Fur resources survey of Wood Buffalo National Park. Canadian Wildlife Service, CWSC 749: 45 pages, tables. [EC-E] [EC-0]

Novakowski, N. S. 1958c. Report on the hatching and planting of rainbow trout Fort Smith, N.W.T., June 10-26, 1958. Canadian Wildlife Service, CWSC 1050: 5 pages. [EC-E] [EC-O]

Novakowski, N.S. 1958d. Report on the testing of killer traps as a substitute for leghold traps. Canadian Wildlife Service. CWSC 772: 8 pages, photographs.

Novakowski, N. S. 1959a. Aerial resurvey of the higher density bison areas in Wood Buffalo Park and the N.W.T. Canadian Wildlife Service, CWSC 883: 5 pages, maps. [EC-E] [EC-O] 
Novakowski, N. S. 1959b. Analysis and appraisal of a three year aerial survey of beaver habitat in the southern and central areas of the Mackenzie District, N.W.T., 1956, 1957, 1958. Canadian Wildlife Service, CWSC 884: 17 pages, tables, maps. [EC-E] [EC-O]

Novakowski, N.S. 1959c. Fish hatchery operations at Pine Lake - June 1959. Canadian Wildlife Service, CWSC 1051: 7 pages. [EC-E] [EC-O]

Novakowski, N. S. 1959d. Report on the investigation of probable Wood Bison in the Nyarling River area and an investigation of historical Wood Bison range in the Fort Providence area. Canadian Wildlife Service, Fort Smith, CWSC 3493: 12 pages, tables, photographs. [EC-E] [EC-O]

Novakowski, N. S. 1961a. Cemental deposition as an age criterion in bison, and the relationship of incisor wear, eyelens weight and dressed bison carcass weight to age. Canadian Wildlife Service, Fort Smith, N.W.T. CWSC 1426: 10 pages [EC-E] [EC-O] See also published version, Novakowski 1965a.

Novakowski, N.S. 1961b. Estimates of the bison population in Wood Buffalo National Park and the Northwest Territories based on transect and total counts. Canadian Wildlife Service, CWSC 882: 6 pages, maps. [EC-E] [EC-O]

Novakowski, N.S. 1961c. Total counts of bison in the higher park density areas of Wood Buffalo Park. Canadian Wildlife Service CWSC 889: 11 pages, illustrations, map. [EC-E] [EC-O]

Novakowski, N.S., and L. P. E. Choquette. 1961 . Report on the testing and slaughter of bison at Sweetgrass, Wood Buffalo National Park. Canadian Wildlife Service, CWSC 1102: 10 pages. [EC-E] [EC-O]

Novakowski, N. S. 1962 . Proposals for a bison management policy. Canadian Wildlife Service: 3 pages. [EC-E]

Novakowski, N.S. 1963a. Report on anthrax in bison in the Hook Lake and Grand Detour areas, N.W.T., 1963. Canadian Wildlife Service: 4 pages. [EC-E]

Novakowski, N. S. 1963b. Report on the transfer of Wood Bison, 1963. Canadian Wildlife Service: 5 pages, maps. [EC-E]

Novakowski, N.S. 1963c. Wood bison transfer: completion report. Canadian Wildlife Service: 4 pages. [EC-E]

Novakowski, N. S., and L. P. E. Choquette. 1963. Bison testing and slaughter at Hay Camp, Wood Buffalo National Park 1963. Canadian Wildlife Service, CWSC 1103: 9 pages. [EC-E] [EC-O]

Novakowski, N. S. 1964a. The effect of disease syndromes on the ecology of the bison in Wood Buffalo National Park. Canadian Wildlife Service: 9 pages. [EC-E]

Novakowski, N. S. 1964b. Report and recommendations concerning the occurrence and control of anthrax in bison in Wood Buffalo National Park and vicinity. Canadian Wildlife Service: 5 pages, maps. [EC-E]

Novakowski, N.S. 1964c. Report on the assessment of proposed bison range in the Saskatchewan River delta. Canadian Wildlife Service: 11 pages, illustrations, table, maps. [EC-E]

Novakowski, N. S. 1964d. Slaughter report - Hay Camp, November 1964. Canadian Wildlife Service, CWSC 1104: 9 pages. [EC-E] [EC-O]

Novakowski, N. S. 1964e. The use of eye-lens weight, tooth replacement, cementum deposition and dressed weight as aging criteria in the bison. Canadian Wildlife Service: 11 pages, illustrations. [EC-E]

Novakowski, N.S. 1965a. Population dynamics of a beaver population in northern latitudes. Ph.D. thesis, University of
Saskatchewan, CWSC 1019: $\mathrm{x}+154$ pages, figures. [EC-E] [EC-0]

Novakowski, N. S. 1965b. The effects of disease upon bison, Mackenzie District. Canadian Wildlife Service, CWSC 1696: 2 pages. [EC-E] [EC-O]

Novakowski, N.S. 1965c. Possible bison range, Cumberland marshes. Canadian Wildlife Service: 2 pages, maps. [EC-E]

Novakowski, N. S. 1965d. Slaughter report, Grand Detour, 1964-65. Canadian Wildlife Service, CWSC 1105: 2 pages. [EC-E] [EC-O]

Novakowski, N. S. 1965e. Wilderness rescue of an injured whooping crane: parents try and [sic] fend off an invading helicopter in the wild muskegs of northern Canada. Canadian Wildlife Service: 5 pages. [EC-E]

Novakowski, N. S., and W. E. Stevens. 1965. Survival of wood bison (Bison bison athabascae Rhodes) in Canada. Canadian Wildlife Service, Edmonton, 5 pages. [EC-E] [Paper delivered to the $45^{\text {th }}$ annual meeting of the American Society of Mammalogists, Winnipeg, 20-26 June, 1965. An abstract is filed under CWSC 1020 in EC-O.]

Novakowski, N. S. 1967a. Anticipated ecological effects of possible changes in the water levels of the Peace RiverAthabasca River delta as a result of the damming of the Peace River. Canadian Wildlife Service, CWSC 1086: 17 pages, maps. [EC-E] [EC-O]

Novakowski, N. S. 1967b. Bighorn sheep study meeting, Edmonton, February 28, 1967. Canadian Wildlife Service: 10 pages. [EC-E]

Novakowski, N.S. 1967c. Concepts of multiple-use and integrated resource management. Canadian Wildlife Service: 10 pages. [EC-E]

Novakowski, N. S. 1967d. Investigation of the Killdeer-Val Marie area in southern Saskatchewan as possible bison range. Canadian Wildlife Service, CWSC 1085: 9 pages, [+2] , maps. [EC-E] [EC-O]

Novakowski, N. S. 1967e. Rare and endangered mammals in Canada. Canadian Wildlife Service, CWSC 2991: 141 pages. [EC-E] [EC-O]

Novakowski, N. S. 1967f. Wood Buffalo National Park. Canadian Wildlife Service: 8 pages, map. [EC-E]

Novakowski, N. S., and L. G. Blight. 1967. Investigation of Athabasca delta to assess feasibility, cost of constructing a rock plug and subsequent effects resulting from restricting the flow of water from the Lake Claire area. Canadian Wildlife Service. CWSC 1357: 5 pages, photographs, chart, map. [EC-E] [EC-O]

Novakowski, N. S., and G. More. 1967. Mammalian pest and predator problems in Canada. Canadian Wildlife Service, Ottawa. CWSC 1703: 67 pages. [EC-E] [EC-O]

Novakowski, N. S., and G. More. no date. Contributions toward a national pest control policy for Canada - mammals. Canadian Wildlife Service, CWSC 3444: 56 pages. [EC-E] [EC-O]

Novakowski, N. S. 1970. Fire priority report, Wood Buffalo National Park. Canadian Wildlife Service, CWSC 1305: 6 pages, maps. [EC-E] [EC-O]

Novakowski, N. S. 1971a. An overview study of the tourist potential of the Northwest Territories - wildlife. Canadian Wildlife Service, CWSC 1370: 8 pages. [EC-E] [EC-O]

Novakowski, N. S. 1971b. Report to the National Energy Board on staffing requirements for an Environmental Division. CWSC 1369: 5 pages, 10 appendices, chart. [EC-O]

Novakowski, N. S. 1975. Evidence concerning impacts of pipelines on rare and endangered species and aquatic and terrestrial animals. Paper presented to the Mackenzie Pipe- 
line enquiry at the request of the Canadian Arctic Resources Committee. Canadian Wildlife Service, CWSC 2143: 33 pages, appendices. [EC-E] [EC-O]

Novakowski, N. S., G. More, and P. Reilly. 1975. Exotic mammals and birds in Canada - a historical review. Canadian Wildlife Service, CWSC 1704: 47 pages. [EC-E] [EC-O]

Novakowski, N. S., and T. Mosquin. 1986a. Caribou Management Plan; Pukaskwa National Park, Volume I. 53 pages. Natural Resource Conservation, Ontario Region, Environment Canada, Ottawa. Consultant Report to Parks Canada by Mosquin Bio-Information Limited, Box 279 Lanark, Ontario.

Novakowski, N. S., and T. Mosquin. 1986b. Caribou Management Plan; Pukaskwa National Park, Volume II (Implementation Strategy). 32 pages. Natural Resource Conservation, Ontario Region, Environment Canada, Ottawa. Consultant Report to Parks Canada by Mosquin BioInformation Limited, Box 279 Lanark, Ontario.

Novakowski, N. S., and T. Mosquin. 1986c. Furbearer Management Plan; Pukaskwa National Park, Volume I. 69 pages. Natural Resource Conservation, Ontario Region, Environment Canada, Ottawa. Consultant Report to Parks Canada by Mosquin Bio-Information Limited, Box 279 Lanark, Ontario.

Novakowski, N. S., and T. Mosquin. 1986d. Furbearer Management Plan; Pukaskwa National Park, Volume II (Implementation Strategy). 69 pages. Natural Resource Conservation, Ontario Region, Environment Canada, Ottawa.
Consultant Report to Parks Canada by Mosquin BioInformation Limited, Box 279 Lanark, Ontario.

Novakowski, N. S. 1989. Historical origin of National Park Plains Bison. Environment Canada, Canadian Park Service, Natural Resources Branch, Ottawa. 31 pages.

Novakowski, N. S. 1990. Northern Diseased Bison Environmental Assessment Panel compendium of supplementary submissions, March 1990. Federal Environmental Assessment Review Office, Ottawa. 308 pages, maps. [EC-E]

Novakowski, N. S., and H. J. Dirschl. 1992. Assessment of priority sites for the establishment of a Network of Conservation Areas by the Canadian Wildlife Service. Environmental Social Advisory Services (ESAS) Inc., Ottawa, Ontario.

Dirschl, H., N. S. Novakowski, and L. C. N. Burgess. 1992. An overview of the biophysical environmental impact of existing uranium mining operations in northern Saskatchewan. vi +90 pages, appendices. Report prepared for the Saskatchewan Uranium Mine Development Review Panel. Environmental Social Advisory Services (ESAS) Inc., Ottawa, Ontario.

Novakowski, N. S. 1997. The beaver in Canada. A textual and visual exposition of the life history of the beaver, Castor canadensis. A report commissioned by the Stamp Products Division of the Canada Post Corporation. ii + 35 pages, illustrations.

Received 13 January 2006

Accepted 3 May 2006 